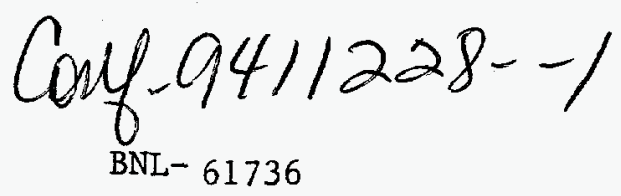

\title{
USDOE STUDY: HUMAN HEALTH AND ECOLOGICAL RISK ASSESSMENTS FOR PRODUCED WATER DISCHARGES
}

\author{
A.F. Meinhold, S. Holtzman, M. DePhillips and L.D. Hamilton \\ Biomedical and Environmental Assessment Group \\ Analytical Sciences Division, Department of Applied Science \\ Brookhaven National Laboratory
}

\section{INTRODUCTION}

Produced water generated during the production of oil and gas can contain high concentrations of radionuclides, organics and heavy metals. There are concerns about potential human health and ecological impacts from the discharge of these contaminants to the Gulf of Mexico.

Data collected in the United States Department of Energy (USDOE) field study (Gettleson et al. 1994) are being used in a series of human health and ecological risk assessments. These assessments will support scientifically-based regulation and risk management.

This presentation: summarizes risk assessments performed for produced water discharges; describes how uncertainties in these assessments are guiding data collection efforts in the USDOE field study; and outlines ongoing risk assessment studies.

In these studies, risk assessment is treated as an iterative process. An initial screening-level assessment is performed to identify important contaminants, transport and exposure pathways, and parameters. These intermediate results are used to guide data collection efforts and refinements to the analysis. At this stage in the analysis, risk is described in terms of probabilities; the uncertainties in each measured or modeled parameter are considered explicitly.

\section{PHASE I COASTAL RISK ASSESSMENT}

A screening-level assessment of the health and environmental risks associated with the discharge of radium in produced water to coastal Louisiana was performed for the American Petroleum Institute (Hamilton et al. 1992). This Phase I screeninglevel analysis was based on simple models and conservative, worst-case assumptions. The analysis concluded that no detectable impacts to fishes or shellfish would result from the discharge of radium in produced waters. The study also suggested that risks to human health are small, but that there might be important risks (individual lifetime fatal cancer risk greater than $1 \times 10^{-4}$ ) for an individual ingesting a large amount of seafood harvested near a produced water discharge point over a lifetime. Estimated population risks were similar to those expected for background radium concentrations in the Gulf of Mexico.

\section{PHASE II OFFSHORE RISK ASSESSMENT}

This human health risk assessment was supported by USDOE, and focused on radium in offshore oil field discharges to the Gulf of Mexico (Meinhold et al 1993). The subpopulation most at risk from radium discharged offshore is recreational fishermen and their families. The exposure route of greatest concern is the ingestion of radium in fishes caught near the platforms. 
The analysis was less dependent on simplistic and conservative assumptions than the Phase I coastal risk assessment and used Monte Carlo methods and distributions of parameters to produce a probabilistic analysis of risk.

Two approaches were used: a direct assessment and a predictive modeling analysis. The direct assessment was based on measured concentrations of radium in edible fish sampled near three shallow offshore platforms, and is assumed to represent a "worst-case" analysis. The predictive modeling analysis estimated risks associated with more representative offshore platforms.

\section{Radium in Water and Fish}

In the direct assessment, uniform distributions of radium concentrations in fish were based on field data (Continental Shelf Associates 1992; Steimle \& Associates 1992) for three shallow $(17,19$ and $22 \mathrm{~m}$ depth) offshore platforms in the Gulf of Mexico (Table 1).

For the predictive analysis, a data base for 125 produced water platforms in the Gulf of Mexico (Stephenson and Supernaw 1990; USEPA 1993) was used to describe the range of discharge rates and radium discharge concentrations in the Gulf of Mexico. The Offshore Operators Committee (OOC) model (Brandsma 1983) was used to estimate the average dilution achieved within a $50 \mathrm{~m}$ radius for outfalls in $67 \mathrm{~m}$ of water, discharging 5,000, 15,000 and $25,000 \mathrm{bbl} / \mathrm{d}$. Model results were used to derive an empirical relationship between discharge rate (bbl/d) and average dilution.

In the predictive assessment, a distribution of radium concentration factors was used to estimate the range of radium concentrations in fishes. These concentration factors were derived from a field study conducted near coastal discharges in the Gulf of Mexico (Continental Shelf Associates 1991). Figure 1 shows the predicted distribution of $\mathrm{Ra}-226$ concentrations in fishes living in the plume.

\section{Exposure Parameters and Risk Factors}

Fish intake rates for recreational fishermen and their families were derived from data collected by the National Marine Fisheries Service (NMFS 1991). The parameters and distributions used in the estimation of intake rates for recreational fishermen are given in Table 2 . Figure 2 shows the distribution of the calculated intake rates for recreational fishermen.

Lognormal distributions of the risk factors for $\mathrm{Ra}-226$ and $\mathrm{Ra}-228$ (individual lifetime fatal cancer risk per $\mathrm{pCi} /$ day) were derived from values developed by the United States Environmental Protection Agency (USEPA; Federal Register 1991).

\section{Results}

In the direct risk assessment, median individual lifetime fatal cancer risks to recreational fishermen ranged from $2.8 \times 10^{-6}$ to $7.8 \times 10^{-6}$, and the upper $95 \%$ confidence limit ranged from $1.2 \times 10^{-4}$ to $4.0 \times 10^{-4}$. Individual lifetime risks associated with background radium concentrations in fishes were approximately one order of magnitude smaller. Figure 3 shows the predicted individual lifetime fatal cancer risk distribution for the platform with the highest median individual lifetime fatal cancer risk (South Timbalier, median: $7.0 \times 10^{-6}$ ). 


\section{DISCLAIMER}

Portions of this document may be illegible in electronic image products. Images are produced from the best available original document. 
In the predictive risk assessment, the median incremental individual lifetime fatal cancer risk for the ingestion of fishes living in the plume was $1.7 \times 10^{-7}$ and the upper $95 \%$ confidence limit was $2.0 \times 10^{-8}$. The risk distribution calculated for ingestion of fish living in the total cylinder of water surrounding the platform had a median value of $6.5 \times 10^{-10}$.

The results of the predictive assessment represent estimates of the risk distribution for deep water offshore platforms in Louisiana. These estimates are smaller than the risks estimated in the direct risk assessment because: 1) the platforms studied in the direct assessment were in shallower water and larger impacts are expected; and 2) the direct analysis was based on field data that required conservative assumptions to allow the use of values coded as "less than" the quantitation limit.

\section{UNCERTAINTIES AND THE USDOE FIELD STUDY}

An uncertainty/sensitivity analysis was performed to assess the importance of major uncertainties to the final risk estimates, and to guide further research and data collection efforts. The most important contributors to uncertainty in the final risk estimates are: 1) the parameters that contribute to the estimate of the radium concentration in fish; and 2) the amount of fish caught near produced water discharges that is ingested by recreational fishermen.

Data collection in the USDOE field study is guided by the need to reduce these important uncertainties. This field study will improve the data base for human health and environmental risk assessments by: 1) reducing the quantitation limit for radium measurements in water and edible seafood; 2 ) increasing the number of replicate samples; 3 ) defining background concentrations in water and biota; and 4) surveying seafood consumption patterns of recreational fishermen.

\section{DATA FOR HUMAN HEALTH AND ECOLOGICAL RISK ASSESSMENTS}

Current work is aimed at reviewing and synthesizing data for use in human health and ecological risk assessments for radionuclides, metals and organics in produced water discharged to coastal and offshore Louisiana. Data collection and review are focused on three areas that will support the planned risk assessments: 1) data describing ingestion rates for recreational fishermen; 2) dose-response relationships for human health risk assessment; and 3) data to support quantitative and qualitative ecological risk assessments.

\section{Ingestion Rates for Recreational Fishermen}

The USDOE field study includes a survey of recreational and commercial fishermen in Louisiana and Texas. The survey and associated statistical analyses are being done by Steimle and Associates, Inc. Results from this study will be used to develop distributions of the amount of fish caught near coastal and offshore platforms that is ingested by recreational fishermen.

\section{Dose-response for Human Health Risk}

For contaminants of potential concern, USEPA slope factors and reference doses will be documented and reviewed to identify excessive conservatisms. Where appropriate, more realistic and up-to-date dose-response relationships and uncertainty distributions will be developed from the available literature. 


\section{Ecological Risk}

The current emphasis in this area is to develop a review and synthesis of the available data to support both quantitative and qualitative ecological risk assessments. The emphasis is on data relating to impacts on the Gulf of Mexico.

This data synthesis and review is focused on several kinds of information:

- studies of produced water toxicity;

o USEPA water quality criteria and toxicity studies for individual contaminants;

o sediment quality criteria and toxicity studies;

0 dosimetry for radionuclides;

o effects on benthic communities;

o histopathologic and genotoxic effects in fish;

0 commercially important fisheries; and

0 endangered species and sensitive ecosystems.

\section{ONGOING AND FUTURE RISK ASSESSMENTS}

Risk assessments planned for 1995 and 1996 include an assessment of the human health and environmental impacts associated with the continuing discharge of produced water to Louisiana open bays, and offshore. An analysis based on field studies of the recovery of several sites is also planned to estimate the risk reduction achieved through the elimination of produced water discharges to coastal Louisiana.

These assessments will be supported by data collected in the USDOE field study and by the previously described data review. The first assessment performed will be for the continuing discharge of produced water to Louisiana open bays. Initial steps in this assessment include: 1 ) describe available discharge data and discharging platforms; 2) estimate environmental concentrations of metals, radionuclides and organics; and 3) perform a conservative screening analysis (both human health and ecological) to identify important contaminants, pathways and endpoints. For important contaminants and pathways, a more detailed probabilistic assessment will be performed.

\section{ACKNOWLEDGEMENTS}

This work was supported by the United States Department of Energy, Office of Fossil Energy, with guidance from Dr. Brent Smith as project officer. Work Performed Under Contract No. DE-AC02-76CH000 with the U.S. Department of Energy.

\section{REFERENCES}

Brandsma, M.G. 1983. A state of the art review of modeling of drilling fluids and cuttings. In Proceedings of the workshop on an evaluation of effluent dispersion and fate models for OCS platforms, Santa Barbara, CA. February 7-10, 1983, Volume 2 pp 24-34, MBC Applied Environmental Sciences. 
Continental Shelf Associates. 1991. Measurements of naturally occurring radioactive material (NORM) at three produced water outfalls. Continental Shelf Associates, Inc., Jupiter Florida. prepared for Mid-Continent Oil and Gas Association, Baton Rouge, Louisiana.

Continental Shelf Associates. 1992. Measurements of naturally occurring radioactive material at two offshore production platforms in the northern Gulf of Mexico, preliminary data report. prepared for the American Petroleum Institute, Washington, D.C.

Federal Register. 1991. Environmental Protection Agency, National Primary Drinking Water Regulations; Radionuclides, 40 CFR Parts 141,142, 56:138:33050.

Gettleson, D., A. Hart and B. Graham. 1994. USDOE study: environmental and economic assessment of discharges from the Gulf of Mexico region oil and gas operations. In Proceedings: fifteenth annual Gulf of Mexico information transfer meeting, November 1994. U.S. Department of the Interior, Minerals Management Service, New Orleans, La.

Hamilton, L.D., A.F. Meinhold and J. Nagy. 1992. Health risk assessment for radium discharged in produced waters. In J.P. Ray and F.R. Engelhart. (eds.). Produced Water. New York: Plenum Press pp. 303-314.

Meinhold, A.F., L.D. Hamilton, S. Holtzman and S. Baxter. 1993. Human health risk assessment for radium discharged in produced water offshore Phase II, prepared for Metairie Site Office, U.S. Department of Energy, Metairie, Louisiana, Brookhaven National Laboratory, Upton, New York, 11973, BNL60107.

NMFS. 1991. Marine recreational fishery survey, Atlantic and Gulf coasts, 19871989. U.S. Department of Commerce, National Oceanic and Atmospheric Administration, National Marine Fisheries Service, Silver Springs, Md. Current Fisheries Statistics Number 8904.

Steimle \& Associates. 1992. Fate and effects of radionuclides, data report, prepared for the American Petroleum Institute, Washington, D.C.

Stephenson, M.T. and I.R. Supernaw. 1990. Offshore operators committee 44 platform study, radionuclide analysis results. Texaco, Inc.

USDOC. 1989. American housing survey for the United States in 1987. United States Department of Commerce, U.S. Department of Housing and Urban Development, Washington, D.C. H-150-87.

USEPA. 1993. Produced water radioactivity study, final draft. Office of Science and Technology, Office of Water, United States Environmental Protection Agency, Washington, D.C. 
Ms. Anne Meinhold is an Environmental Research Associate in the Department of Applied Science at Brookhaven National Laboratory. She has a B.S. in Biology from the State University of New York at Stony Brook, and a M.S. in Environmental Science from the University of North Carolina at Chapel Hill. Her research interests focus on environmental risks.

Dr. Seymour Holtzman has worked in the Biomedical and Environmental Assessment Group at Brookhaven National Laboratory since 1990, specializing in health and environmental risk assessments. He received his B.S. and M.A. in Biology from the City College of New York, and his Ph.D. in Biology (Comparative Animal Physiology) from the City University of New York.

Mr. Michael DePhillips has been working as an Associate Environmental Scientist at Brookhaven National Laboratory for the past four years; researching and assessing a variety of environmental issues with regard to energy production, policy and regulation. Mr. DePhillips received a B.A. in Political Science and an M.S. in Environmental Sciences from the State University of New York at Stony Brook.

Dr. Leonard Hamilton was head of the Biomedical and Environmental Assessment Group at Brookhaven National Laboratory for 20 years, and is Professor of Medicine at the State University of New York at Stony Brook, and World Health Organization focal point on Energy and Health. His major area of research interest is environmental risks. Dr, Hamilton, a physician, received his D.M. from Oxford University and his Ph.D. in Experimental Pathology from Cambridge University.

\section{DISCLAIMER}

This report was prepared as an account of work sponsored by an agency of the United States Government. Neither the United States Government nor any agency thereof, nor any of their employees, makes any warranty, express or implied, or assumes any legal liability or responsibility for the accuracy, completeness, or usefulness of any information, apparatus, product, or process disclosed, or represents that its use would not infringe privately owned rights. Reference herein to any specific commercial product, process, or service by trade name, trademark, manufacturer, or otherwise does not necessarily constitute or imply its endorsement, recommendation, or favoring by the United States Government or any agency thereof. The views and opinions of authors expressed herein do not necessarily state or reflect those of the United States Government or any agency thereof. 
Table 1. Uniform distributions of radium concentrations used in direct risk assessment for the Eugene Island, Ship Shoal and South Timbalier platforms (Continental Shelf Associates 1992; Steimle \& Associates 1992).

\begin{tabular}{lll}
\hline Platform & $\begin{array}{l}\mathrm{Ra}-226(\mathrm{pCi} / \mathrm{g}) \\
\text { mean range }\end{array}$ & $\begin{array}{l}\mathrm{Ra}-228(\mathrm{pCi} / \mathrm{g}) \\
\text { mean range }\end{array}$
\end{tabular}

\begin{tabular}{lllll}
\hline Eugene Island & 0.08 & $0-0.16^{*}$ & 0.365 & $0-0.73$
\end{tabular}

Ship Shoal

$0.1350-0.27^{*}$

$0.89 \quad 0-1.78$

South Timbalier

$0.005^{* *} 0-0.01$

$1.35 \quad 0-2.7$

Background

$0.005 \quad 0-0.01$

$0.005 \quad 0-0.01$

* maximum value based on $1 / 2$ a reported "less than quantitation limit" value. no Ra-226 was detected in fishes at South Timbalier, distribution used is assumed background distribution. 
Table 2. Summary of parameters used to estimate the rate of ingestion for fishes caught near offshore platforms (means and standard deviations are arithmetic).

PARAMETER

No. of Fish Caught

Weight of Fish $(\mathrm{kg})$

No. Days Fished (d/yr)

Edible Fraction

Family Size

Maximum Ingestion Rate $(\mathrm{g} / \mathrm{d})$
DISTRIBUTION DESCRIPTION

lognormal, mean: 5.4, sd: 9.2, range: 0.011-116

lognormal, mean: 1.9 , sd: 3.0 , range: $0.1-24.6$

lognormal, mean: 19.5 , sd: 29.6 , range: $1-251$

0.3

data for southern U.S. from USDOC (1989)

150 
Figure 1. Predicted distribution of Ra-226 concentration in fishes living in the plume.

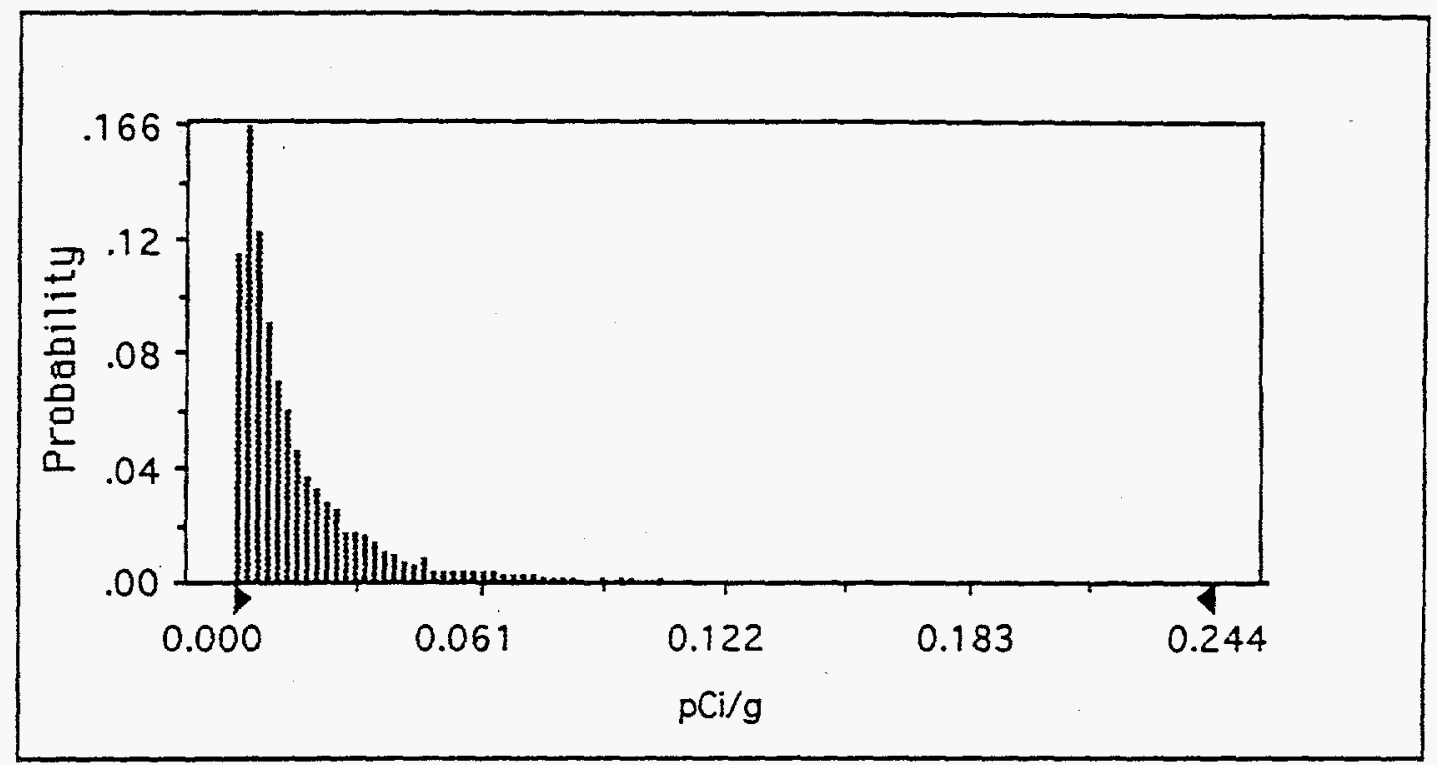


Figure 2. Calculated distribution of ingestion rates for recreational fishermen.

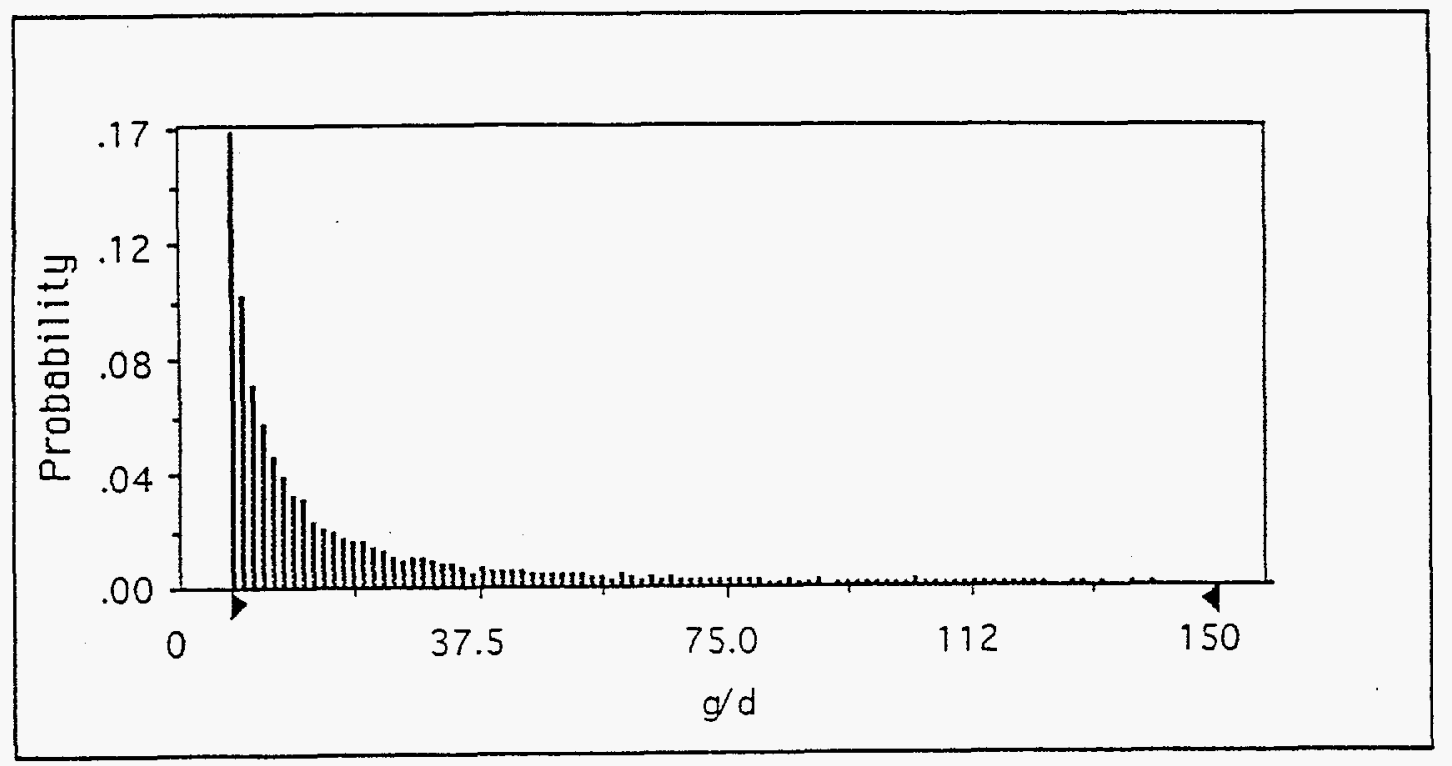


Figure 3. Predicted individual lifetime fatal cancer risk distribution for recreational fishermen at South Timbalier.

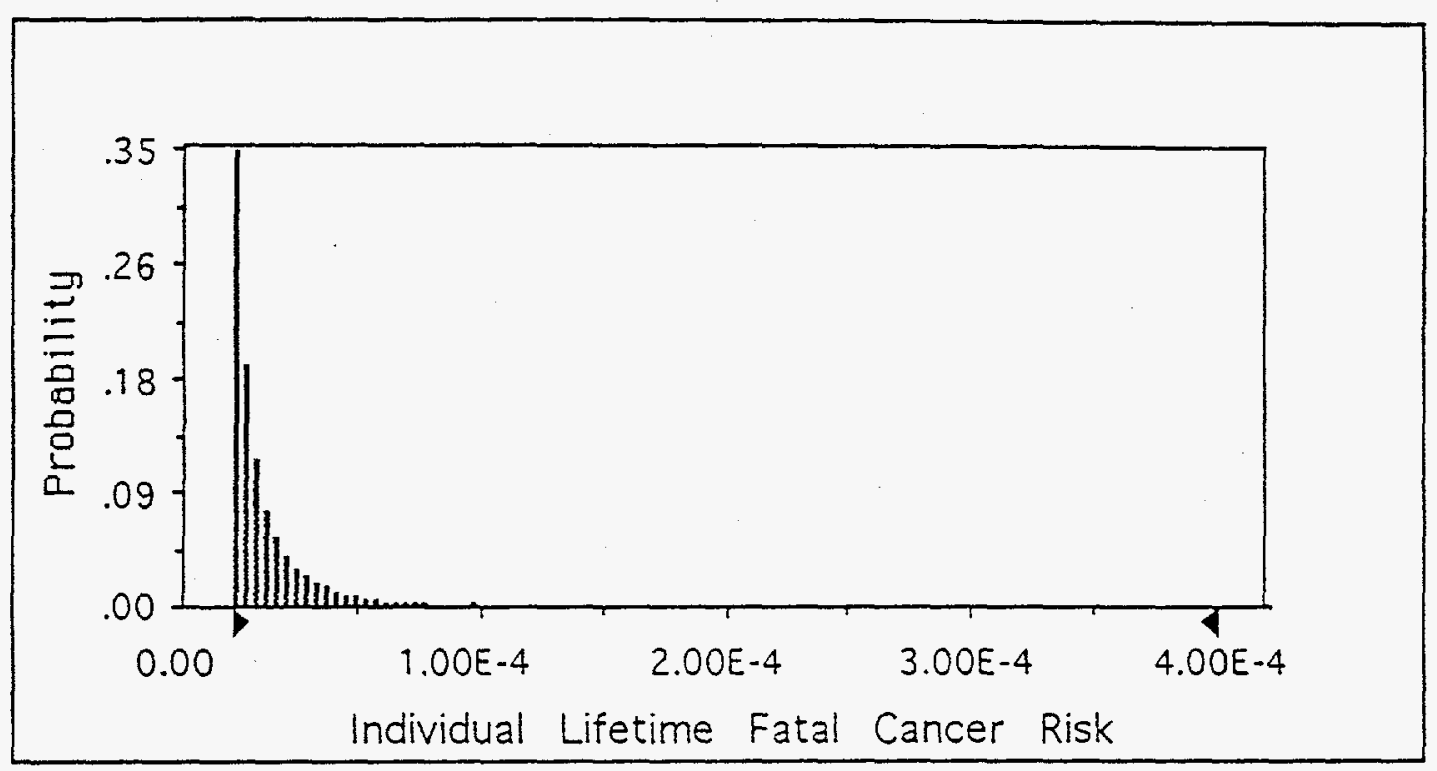

